$S=1.054$

4120 reflections

394 parameters

$\mathrm{H}$ atoms: see below

$w=1 /\left[\sigma^{2}\left(F_{o}^{2}\right)+(0.1171 P)^{2}\right.$

$+0.9778 P]$

where $P=\left(F_{o}^{2}+2 F_{c}^{2}\right) / 3$
Extinction correction: SHELXL93 (Sheldrick, 1993)

Extinction coefficient: $0.0023(5)$

Scattering factors from SHELXL93

Table 1. Selected geometric parameters $\left(\AA^{\circ}{ }^{\circ}\right)$

\begin{tabular}{|c|c|c|c|}
\hline $\mathrm{Cll}-\mathrm{C} 12^{\prime}$ & $1.804(4)$ & $\mathrm{O} 2 A-\mathrm{C} 11$ & $1.253(12)$ \\
\hline $\mathrm{Cl} 2-\mathrm{C} 13^{\prime}$ & $1.816(4)$ & $\mathrm{O} 3 A-\mathrm{C} 11$ & $1.235(13)$ \\
\hline $\mathrm{O} 2-\mathrm{C} 11$ & $1.232(4)$ & $\mathrm{O} 3 A-\mathrm{C} 13$ & $1.601(14)$ \\
\hline $\mathrm{O} 3-\mathrm{Cll}$ & $1.333(4)$ & $\mathrm{Cl}-\mathrm{Cl}^{\prime}$ & $1.504(3)$ \\
\hline $\mathrm{O} 3-\mathrm{Cl} 3$ & $1.432(4)$ & $\mathrm{C} 3-\mathrm{C} 11$ & $1.490(3)$ \\
\hline $\begin{array}{l}\mathrm{C} 11-\mathrm{O} 3-\mathrm{C} 13 \\
\mathrm{C} 11-\mathrm{O} 3 A-\mathrm{C} 13 \\
\mathrm{O} 2-\mathrm{C} 11-\mathrm{O} 3 \\
\mathrm{O} 2-\mathrm{C} 11-\mathrm{C} 3 \\
\mathrm{O} 3 A-\mathrm{C} 11-\mathrm{C} 3\end{array}$ & $\begin{array}{l}116.0(3) \\
110.9(9) \\
121.3(3) \\
125.1(3) \\
110.6(7)\end{array}$ & $\begin{array}{l}\mathrm{O} 2 \mathrm{~A}-\mathrm{C} 11-\mathrm{C} 3 \\
\mathrm{O} 3-\mathrm{C} 11-\mathrm{C} 3 \\
\mathrm{C}^{\prime}-\mathrm{C} 12^{\prime}-\mathrm{Cl} 1 \\
\mathrm{C}^{\prime}-\mathrm{C} 13^{\prime}-\mathrm{Cl} 2\end{array}$ & $\begin{array}{l}114.1(6) \\
113.2(2) \\
111.9(2) \\
111.3(2)\end{array}$ \\
\hline $\begin{array}{l}\mathrm{C} 12-\mathrm{O} 1-\mathrm{C} 2-\mathrm{Cl} \\
\mathrm{C} 13-\mathrm{O} 3 \mathrm{~A}-\mathrm{C} 11-\mathrm{O} 2 \mathrm{~A} \\
\mathrm{C} 13-\mathrm{O}-\mathrm{C} 11-\mathrm{O} 2 \\
\mathrm{C} 4-\mathrm{C} 3-\mathrm{C} 11-\mathrm{O} 2 \\
\mathrm{C} 4-\mathrm{C} 3-\mathrm{C} 11-\mathrm{O} 2 \mathrm{~A}\end{array}$ & $\begin{array}{l}-95.0(3) \\
-14.8(19) \\
-2.0(6) \\
152.0(3) \\
-135.3(8)\end{array}$ & $\begin{array}{l}\mathrm{C} 2-\mathrm{Cl}-\mathrm{Cl}^{\prime}-\mathrm{C}^{\prime} \\
\mathrm{C} 11^{\prime}-\mathrm{O} 4-\mathrm{C}^{\prime}-\mathrm{Cl}^{\prime} \\
\mathrm{C}^{\prime}-\mathrm{C} 3^{\prime}-\mathrm{C} 12^{\prime}-\mathrm{Cl1} \\
\mathrm{C}^{\prime}-\mathrm{C}^{\prime}-\mathrm{C} 13^{\prime}-\mathrm{Cl} 2\end{array}$ & $\begin{array}{r}-85.5(3) \\
-92.1(3) \\
-100.3(3) \\
96.9(3)\end{array}$ \\
\hline
\end{tabular}

All $\mathrm{H}$-atom parameters were refined except those of $\mathrm{H} 135$ where only the $\mathrm{H}$-atom $U$ value was refined. $\mathrm{C}-\mathrm{H}$ distances are in the range $0.78(3)-1.02(4) \AA$ and $U_{\text {iso }}$ values are in the range $0.044(7)-0.15(2) \AA^{2}$ for the refined $H$ atoms. Atoms O2/O2A and O3/O3A have occupancies of $0.801(9) / 0.199(9)$.

Data collection: SDP (B. A. Frenz \& Associates Inc., 1982). Cell refinement: SDP. Data reduction: SDP. Program(s) used to solve structure: SHELXS86 (Sheldrick, 1990). Program(s) used to refine structure: SHELXL93 (Sheldrick, 1993). Software used to prepare material for publication: $S H E L X L 93$.

Supplementary data for this paper are available from the IUCr electronic archives (Reference: FR 1060). Services for accessing these data are described at the back of the journal.

\title{
References
}

Akimoto, H. \& Iitaka, Y. (1969). Acta Cryst. B25, 1491-1500.

B. A. Frenz \& Associates Inc. (1982). SDP Structure Determination Package. College Station, Texas, USA.

Bell, T. W. (1996). Science, 271, 1077-1078.

Filippakis, S. E., Leiserowitz, L. \& Schmidt, G. M. J. (1967). J. Chem. Soc. B, pp. 290-296.

Issberner, J., Moors, R. \& Voegtle, F. (1994). Angew. Chem. Int. Ed. Engl. 33, 2413-2419.

Lellek, V. \& Stibor, I. (1997). Collect. Czech. Chem. Commun. 62 , 925-940.

Mekelburger, H.-B., Jaworek, W. \& Voegtle, F. (1992). Angew. Chem. Int. Ed. Engl. 31, 1571-1576.

Newkome, G. R. \& Moorefield, C. N. (1996). Comprehensive Supramolecular Chemistry, Vol. 10, edited by J.-M. Lehn, pp. 777832. Oxford: Pergamon, Elsevier Science.

Newkome, G. R., Moorefield, C. N. \& Baker, G. R. (1992), Aldrichim. Acta, 25, 31-38.

North, A. C. T., Phillips, D. C. \& Mathews, F. S. (1968). Acta Cryst. A24, 351-359.

Ondráček, J., Pakhomova, S., Hovorka, M. \& Ščigel, R. (1993). Z. Kristallogr. 208, 269-273.

Ondráček, J., Pakhomova, S., Novotný, J., Hovorka, M. \& Ščigel, R. (1994). Acta Cryst. C50, 137-139.

Sheldrick, G. M. (1990). Acta Cryst. A46, 467-473.

Sheldrick, G. M. (1993). SHELXL93. Program for the Refinement of Crystal Structures. University of Göttingen, Germany.

(C) 1997 International Union of Crystallography

Printed in Great Britain - all rights reserved

Stibor, I. \& Lellek. V. (1994). Chem. Listy, 88, 423-449.

Tomalia, D. A. \& Durst, H. D. (1993). Topics in Current Chemistry, Vol. 165, edited by E. Weber, pp. 193-319. Berlin: Springer Verlag. Tomalia, D. A., Naylor, A. M. \& Goddard, W. A. III (1990). Angew. Chem. Int. Ed. Engl. 29, 138-175.

Acta Cryst. (1997). C53, 1873-1875

\section{A 2:1 Co-Crystal of Hydroquinone and 3,5-Bis(2-pyridyl)-1,2,4-triazole}

\author{
M. NieuWenhuYzen, ${ }^{a}$ T. E. Keyes ${ }^{b}{ }^{\text {J. F. FallagheR }}{ }^{b}$ \\ AND J. G. $\operatorname{Vos}^{b}$ \\ ${ }^{a}$ School of Chemistry, The Queen's University, Belfast \\ BT9 5AG, Northern Ireland, and ${ }^{b}$ School of Chemical \\ Sciences, Dublin City University, Glasnevin, Dublin 9, \\ Ireland.E-mail: woody.m@qub.ac.uk
}

(Received 8 April 1997; accepted 30 June 1997)

\section{Abstract}

The title compound, $2 \mathrm{C}_{12} \mathrm{H}_{9} \mathrm{~N}_{5} \cdot \mathrm{C}_{6} \mathrm{H}_{6} \mathrm{O}_{2}$, exhibits a three-dimensional hydrogen-bonded network of $\mathrm{N}$ $\mathrm{H} \cdots \mathrm{N}, \mathrm{C}-\mathrm{H} \cdots \mathrm{N}, \mathrm{O}-\mathrm{H} \cdots \mathrm{N}, \mathrm{C}-\mathrm{H} \cdots \mathrm{O}, \mathrm{C}-\mathrm{H} \cdots \pi$ and $\pi \cdots \pi$ interactions.

\section{Comment}

Recently, the synthesis and physical properties of a series of ruthenium(II)-polypyridyl complexes containing triazole ligands with pendant phenol (Hage, Haasnoot, Reedijk et al., 1990) and hydroquinone (Wang et al., 1993) moieties have been reported. In these studies, crystallographic, spectroscopic and electrochemical evidence was obtained for the presence of intermolecular hydrogen bonding in these complexes involving the hydroxy groups and the free $\mathrm{N}$ atoms of the triazole rings. On the basis of these results, we believe that a systematic investigation of the hydroquinone-pyridyltriazole solid-state systems will lead to the development of new materials with interesting electron- and protontransfer properties.

The bond lengths and angles for the bis(pyridyl)triazole (Hbpt) moieties are consistent with those found for the coordinated species in the mono- and binuclear ruthenium complexes $\left[\mathrm{Ru}(\mathrm{bpy})_{2}(\mathrm{bpt})\right] \mathrm{PF}_{6} \cdot 0.5 \mathrm{H}_{2} \mathrm{O}$ and $\left[\mathrm{Ru}(\mathrm{bpy})_{2}(\mathrm{bpt})\right]\left(\mathrm{CF}_{3} \mathrm{SO}_{3}\right) \cdot 4 \mathrm{H}_{2} \mathrm{O}$ (Hage et al., 1989; Hage, Haasnoot, Nieuwenhuis et al., 1990).<smiles>c1ccc(-c2n[nH]c(-c3ccccn3)n2)nc1</smiles><smiles>CC(C)OC(=O)O</smiles>

Acta Crystallographica Section C ISSN 0108-2701 (C) 1997 


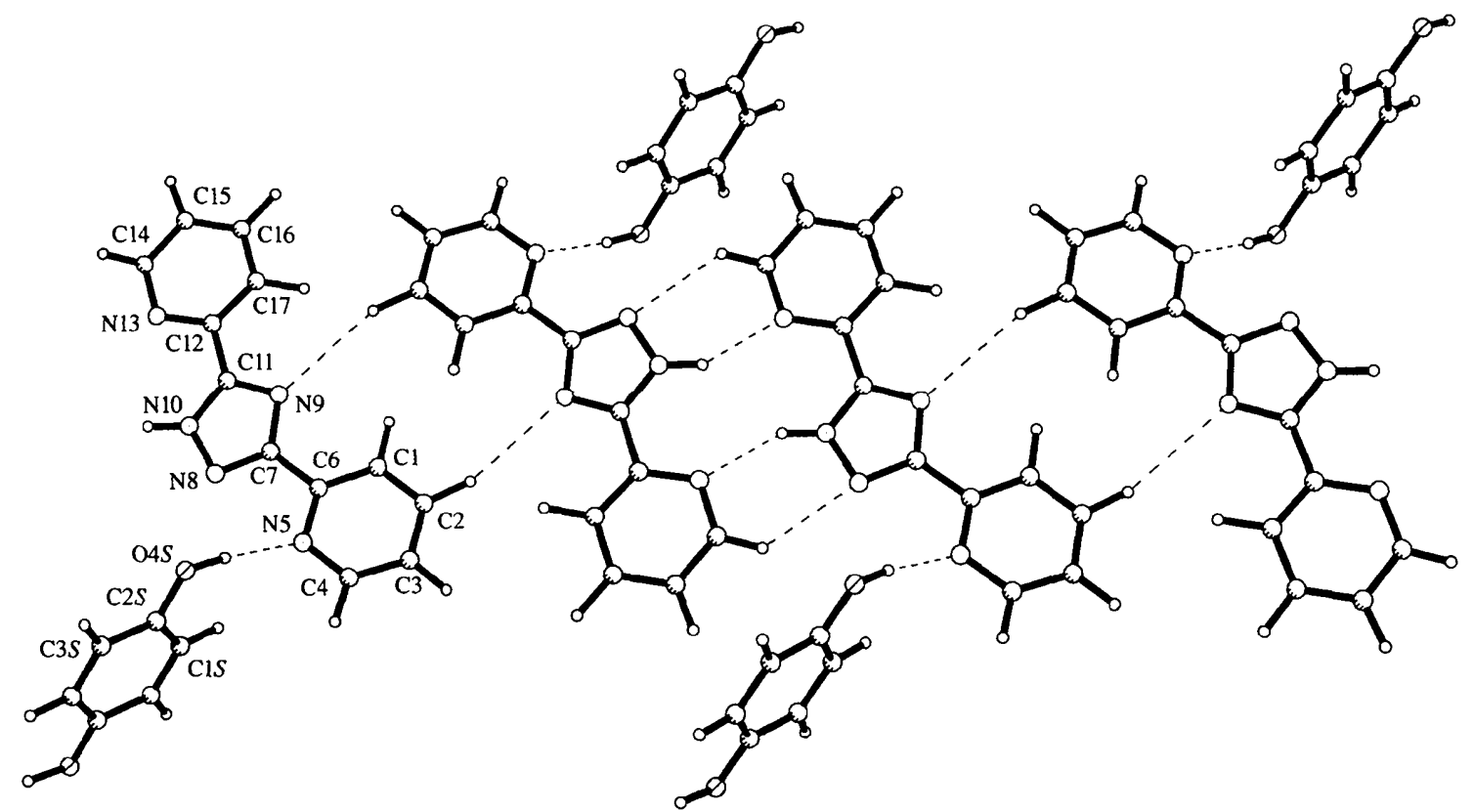

Fig. 1. The atomic labelling scheme and geometry showing a hydrogen-bonded tape of Hbpt and hydroquinone molecules. The hydroquinone molecules are located about inversion centres and provide a link between hydrogen-bonded tapes forming a three-dimensional hydrogenbonded network. The dashed lines indicate hydrogen bonds and neighbouring tapes have been omitted for clarity.

The asymmetric unit contains one $\mathrm{Hbpt}$ molecule and half a hydroquinone situated about an inversion centre. The $\mathrm{Hbpt}$ molecules form dimers via $\mathrm{C}$ $\mathrm{H} \cdots \mathrm{N}$ (pyridyl-to-triazole) and $\mathrm{N}-\mathrm{H} \cdots \mathrm{N}$ (triazole-topyridyl) hydrogen bonds. The dimers are then extended into chains in the [101] direction by another C$\mathrm{H} \cdots \mathrm{N}$ hydrogen bond from a pyridyl moiety to the triazole moiety. This second $\mathrm{C}-\mathrm{H} \cdots \mathrm{N}(\mathrm{C} 2-\mathrm{H} 2 \cdots \mathrm{N} 9)$ interaction is much weaker than the other and is hindered by the presence of two pyridyl $\mathrm{H}$ atoms, $\mathrm{H} 1$ and $\mathrm{H} 17$, causing the pyridyl rings to be twisted out of the plane of the triazole ring. The degree of twist is different for the two pyridyl rings, being $12.0(1)^{\circ}$ for the $\mathrm{C} 1$ ring and $4.9(1)^{\circ}$ for the $\mathrm{C} 12$ ring (Fig. 1) and is a result of the asymmetric nature of the $\mathrm{H} \cdot \mathrm{H}$ repulsions; $c f$. $\mathrm{C} 1 \cdots \mathrm{C} 2^{\mathrm{i}} 4.087(3)$ and $\mathrm{C} 17 \cdots \mathrm{C} 2^{\mathrm{i}}$ 3.715 (3) $\AA$ [symmetry code: (i) $-x, 1-y, 1-z$ ].

The chains of Hbpt molecules are stacked in the [100] direction and are involved in $\pi \cdots \pi$ interactions (3.5-3.9 $\AA$ ) with adjacent hydrogen-bonded chains (Table 1). The hydroquinone molecules bridge between these chains via $\mathrm{O}-\mathrm{H} \cdots \mathrm{N}$ and $\mathrm{C}-\mathrm{H} \cdots \mathrm{N}$ hydrogen bonds to the pyridyl $\mathrm{N}$ atom not involved in the dimer formation. They are also linked to the $\mathrm{Hbpt}$ molecules via $\mathrm{C}-\mathrm{H} \cdots \mathrm{O}$ and $\mathrm{C}-\mathrm{H} \cdots \pi$ interactions from the pyridyl moiety (Table 1 ). This creates a threedimensional hydrogen-bonded network with the hydroquinone molecules acting as links between adjacent chains of $\mathrm{Hbpt}$ molecules. It is notable that there are no interactions between the hydroquinone molecules and that they form a herring-bone arrangement with respect to the Hbpt molecules.

\section{Experimental}

1,4-Dihydroxybenzene (Aldrich) was purified by recrystallization from ethanol and Hbpt was prepared as reported in the literature (Hage et al., 1988). Co-crystals were obtained by refluxing $\mathrm{Hbpt}$ and hydroquinone in a 2:1 ratio in an ethanolwater solution. Upon cooling of the solution, tan-coloured rodlike crystals were obtained (m.p. 471.5-473.5 K).

\section{Crystal data}

$2 \mathrm{C}_{12} \mathrm{H}_{9} \mathrm{~N}_{5} . \mathrm{C}_{6} \mathrm{H}_{6} \mathrm{O}_{2}$ $M_{r}=556.59$

Triclinic

$P \overline{1}$

$a=7.3223(7) \AA$

$b=7.6708(6) \AA$

$c=13.2160(10) \AA$

$\alpha=105.062(9)^{\circ}$

$\beta=92.139(8)^{\circ}$

$\gamma=110.002(9)^{\circ}$

$V=667.03(14) \AA^{3}$

$Z=1$

$D_{x}=1.386 \mathrm{Mg} \mathrm{m}^{-3}$

$D_{m}$ not measured

Data collection

Siemens $P 4$ diffractometer

$\omega$ scans

Absorption correction: none

2513 measured reflections

2312 independent reflections

1642 reflections with

$I>2 \sigma(I)$

$R_{\text {int }}=0.015$
Mo $K \alpha$ radiation

$\lambda=0.71073 \AA$

Cell parameters from 35 reflections

$\theta=5.0-12.5^{\circ}$

$\mu=0.093 \mathrm{~mm}^{-1}$

$T=120(2) \mathrm{K}$

Needle

$0.65 \times 0.34 \times 0.19 \mathrm{~mm}$

Light $\tan$ $\theta_{\max }=25^{\circ}$
$h=0 \rightarrow 8$
$k=-8 \rightarrow 8$
$l=-15 \rightarrow 15$
3 standard reflections
$\quad$ every 97 reflections
intensity variation: $1 \%$ 
Refinement

Refinement on $F^{2}$

$R\left[F^{2}>2 \sigma\left(F^{2}\right)\right]=0.048$

$w R\left(F^{2}\right)=0.107$

$S=1.083$

2312 reflections

190 parameters

$\mathrm{H}$ atoms were located from $\Delta F$ synthesis and refined using a riding model

$$
\begin{gathered}
w=1 /\left[\sigma^{2}\left(F_{o}^{2}\right)+(0.0587 P)^{2}\right. \\
+0.1659 P] \\
\text { where } P=\left(F_{o}^{2}+2 F_{c}^{2}\right) / 3 \\
(\Delta / \sigma)_{\max }<0.001 \\
\Delta \rho_{\max }=0.16 \AA^{-3} \\
\Delta \rho_{\min }=-0.22 \mathrm{e}^{-3}
\end{gathered}
$$

Extinction correction: none

Scattering factors from

International Tables for

Crystallography (Vol. C)

Table 1. Hydrogen-bonding geometry $\left(\AA,^{\circ}\right)$

\begin{tabular}{lllll}
\multicolumn{1}{c}{$D-\mathrm{H} \cdots A$} & $D-\mathrm{H}$ & $\mathrm{H} \cdots A$ & $D \cdots A$ & $D-\mathrm{H} \cdots A$ \\
$\mathrm{O} 4 \mathrm{~S}-\mathrm{H} 4 S \cdots \mathrm{N} 5$ & 1.05 & $1.816(3)$ & $2.844(3)$ & $163.77(8)$ \\
$\mathrm{N} 10-\mathrm{H} 10 \cdots \mathrm{N} 13^{\prime}$ & 0.98 & $2.067(3)$ & $2.953(3)$ & $149.56(7)$ \\
$\mathrm{C} 14-\mathrm{H} 14 \cdots \mathrm{N}^{\prime}$ & 1.04 & $2.520(3)$ & $3.301(3)$ & $131.57(7)$ \\
$\mathrm{C} 2-\mathrm{H} 2 \cdots \mathrm{N}^{\prime \prime}$ & 1.14 & $2.852(3)$ & $3.931(3)$ & $156.94(6)$ \\
$\mathrm{C} 16-\mathrm{H} 16 \cdots \mathrm{O} 4 S^{\prime \prime \prime}$ & 1.18 & $2.646(3)$ & $3.379(3)$ & $118.80(7)$ \\
$\mathrm{C} 3-\mathrm{H} 3 \cdots \mathrm{O} 4 S^{\mathrm{iv}}$ & 1.11 & $2.535(3)$ & $3.521(3)$ & $147.69(7)$ \\
$\mathrm{C} 15-\mathrm{H} 15 \cdots \mathrm{C} 1 S^{*}$ & 1.06 & $2.836(3)$ & $3.769(3)$ & $146.99(7)$ \\
$\mathrm{C} 15-\mathrm{H} 15 \cdots \mathrm{C} 2 S^{\mathrm{v}}$ & 1.06 & $2.704(3)$ & $3.759(3)$ & $173.83(7)$ \\
$\mathrm{C} 15-\mathrm{H} 15 \cdots \mathrm{C} 3 S^{\prime}$ & 1.06 & $2.841(3)$ & $3.788(3)$ & $148.82(7)$ \\
Symmetry codes: (i) $1-x, 3-y, 1-z ;(\mathrm{ii})-x, 1-y, 1-z ;(\mathrm{iii})$ \\
$-x, 2-y, 1-z ;$ (iv) $x, y-1, z ;(\mathrm{v}) x, 1+y, 1+z$.
\end{tabular}

Data collection: XSCANS (Fait, 1993). Cell refinement: XSCANS. Data reduction: XSCANS. Program(s) used to solve structure: SHELXS86 (Sheldrick, 1990a). Program(s) used to refine structure: SHELXL93 (Sheldrick, 1993). Molecular graphics: SHELXTL/PC (Sheldrick, 1990b). Software used to prepare material for publication: $S H E L X T L / P C$.

Supplementary data for this paper are available from the $\mathrm{IUCr}$ electronic archives (Reference: BMI161). Services for accessing these data are described at the back of the journal.

\section{References}

Fait, J. (1993). XSCANS. Siemens Analytical X-ray Instruments Inc., Madison, Wisconsin, USA.

Hage, R., Dijkhuis, A. H. J., Haasnoot, J. G., Prins, R. \& Reedijk, J. (1988). Inorg. Chem. 27, 2185-2198.

Hage, R., Haasnoot, J. G., Nieuwenhuis, H. A., Reedijk, J., de Riddler, D. J. A. \& Vos, J. G. (1990). J. Am. Chem. Soc. 112, 9245-9252.

Hage, R., Haasnoot, J. G., Reedijk, J., Turkenberg, J. P. \& de Graaf, R. A. G. (1989). Acta Cryst. C45, 381-383.

Hage, R., Haasnoot, J. G.. Reedijk. J., Wang, R., Ryan, E. M., Vos, J. G., Spek, A. L. \& Duisenberg, A. J. M. (1990). Inorg. Chim. Acta, 174, 77-85.

Sheldrick, G. M. (1990a). Acta Cryst. A46, 467-473.

Sheldrick, G. M. (1990b). SHELXTL/PC. An Integrated System for Data Collection, Processing, Structure Solution and Refinement. Siemens Analytical X-ray Instruments Inc., Madison, Wisconsin, USA.

Sheldrick, G. M. (1993). SHELXL93. Program for the Refinement of Crystal Structures. University of Göttingen, Germany.

Wang, R., Keyes, T. E., Hage, R., Schmehl, R. H. \& Vos, J. G. (1993).

J. Chem. Soc. Chem. Commun. pp. 1652-1654.

(C) 1997 International Union of Crystallography Printed in Great Britain - all rights reserved

Acta Cryst. (1997). C53, 1875-1877

\section{Polysulfonylamines. XCI. $\dagger$ Ethylammonium Di(benzenesulfonyl)amide $1,4,7,10,13,16$ - Hexaoxacyclooctadecane (1/1/1)}

\section{Dagmar Henschel, Armand Blaschette and Peter G. JONES*}

Institut für Anorganische und Analytische Chemie, Technische Universität Braunschweig, Postfach 3329, 38023 Braunschweig, Germany.E-mail: jones@xray36.anchem.nat. tu-bs.de

(Received 16 May 1997; accepted 9 July 1997)

\section{Abstract}

In the structure of the title compound, $\mathrm{C}_{2} \mathrm{H}_{8} \mathrm{~N}^{+} \cdot \mathrm{C}_{12} \mathrm{H}_{10^{-}}$ $\mathrm{NO}_{4} \mathrm{~S}_{2}^{-} \cdot \mathrm{C}_{12} \mathrm{H}_{24} \mathrm{O}_{6}$, the non-coordinating $\left(\mathrm{C}_{6} \mathrm{H}_{5} \mathrm{SO}_{2}\right)_{2} \mathrm{~N}^{-}$ anion adopts an extended conformation with the phenyl groups lying on opposite sides of the $\mathrm{S}-\mathrm{N}-\mathrm{S}$ plane. The conformation of the macrocycle and the hydrogenbond geometry in the complex cation closely resemble those in related adducts between 18-crown-6 and primary alkylammonium salts.

\section{Comment}

We are interested in the structures of polysulfonylamines in general and in the conformation of di(benzenesulfonyl)amine in particular. Di(benzenesulfonyl)amine, $\mathrm{HN}\left(\mathrm{SO}_{2} \mathrm{C}_{6} \mathrm{H}_{5}\right)_{2}$, adopts an extended conformation in the solid state, the $\mathrm{N}\left(\mathrm{SO}_{2} \mathrm{C}\right)_{2}$ moiety approximating to $C_{2}$ symmetry, whereas in the corresponding sodium salt the conjugate anion has a folded pseudo- $C_{s}$ symmetry that favours close contacts between $\mathrm{Na}^{+}$and the electronegative $\mathrm{N}$ and $\mathrm{O}$ atoms (Cotton \& Stokely, 1970).
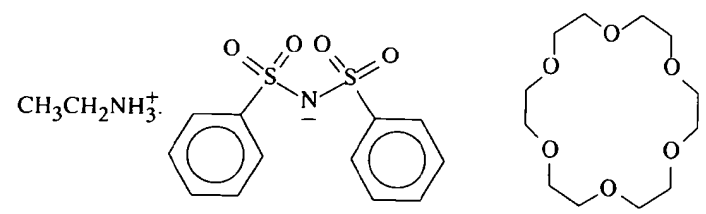

(1)

In contrast to the $\mathrm{Na}$ salt, the title compound, (1), consists of a large organic cation, with effectively shielded charge, and a non-coordinating $\left(\mathrm{C}_{6} \mathrm{H}_{5} \mathrm{SO}_{2}\right)_{2} \mathrm{~N}^{-}$ anion (Fig. 1). The closest cation-anion contact is observed between a methylene $\mathrm{H}$ and a sulfonyl $\mathrm{O}$ atom $[\mathrm{H} 40 \mathrm{O} \ldots \mathrm{O} 92.80, \mathrm{C} 40 \cdots \mathrm{O} 9 \mathrm{3} 314$ (4) $\AA$ and $\mathrm{C} 40$ $\mathrm{H} 40 D$. O $\left.9113^{\circ}\right]$. In this environment, the anion adopts an extended conformation resembling that of its parent acid; however, the deviation of the $\mathrm{N}\left(\mathrm{SO}_{2} \mathrm{C}\right)_{2}$ group

† Part XC: Wijaya, Moers, Blaschette \& Jones (1997). 